\title{
Government Debt, Money, and Economic Activity ${ }^{1}$
}

\author{
by KENNETH STEWART
}

\begin{abstract}
T
HE AMERICAN economy in the last six years has experienced a high rate of inflation. The recent recession, which led to an increase in the rate of unemployment, was not accompanied by a rapid reduction in the rate of inflation. As a result, the effectiveness of traditional stabilization measures was questioned, and the New Economic Program, which includes administrative controls on prices and wages, was initiated as a solution to these problems.

An examination of economic evidence over the past twenty years suggests that the course of monetary expansion can explain both the emergence of inflation in the mid-1960s and the occurrence of a high unemployment rate at the turn of this decade. The pattern of monetary growth has been, in turn, greatly influenced by growth in Federal Government debt.

This article relates trend rates of growth of money and changes in rates of monetary growth during the past two decades to changes in output, employment, and prices. It further analyzes the growth of Government debt and its relationship to the expansion of the money stock.
\end{abstract}

\section{Money and Economic Activity}

According to the view presented in this article, the economy is considered to be basically stable and in the long run to move along a trend path of output determined by growth in its productive potential. Some variation in output and employment around

This article expands some of the views initially presented in a speech by Darry $R$. Francis at the Annual Internountain Banking Seminar, Utah State Unversity, Logan, Utah, November 18,1971 , as well as in papers presented by Leonall C. Andersen at the Nineteenth Arnual Conference on the Lconomic Outlook, The University of Michigan. Ann Arbor, Michigan, Novenber 18, 1971, and by Jerry L. Jordan at the National Bureau of Economic Research Conferetsce on Secü lar Inflation, Chicago, Illinois, November 5 and $6,1971$. the trend path occurs due to disturbances from labor strikes, crop failures, changes in tax rates and other factors, but these disturbances have seldom been the dominant force in causing recessions or inflations.

Evidence indicates that marked and sustained changes in the rate of monetary expansion have been a major factor underlying virtually all cyclical fluctuations and inflations. Changes in the rate of growth of the money stock have been shown to have predictable effects on total spending in the same direction. ${ }^{2}$ Changes in total spending have been associated first with changes in output and later with changes in prices." Consequently, the trend rate of growth of the money stock, defined in this article as demand deposits and currency held by the nonbank public, is viewed as having a major influence in determining the trend rate of growth of prices, whereas accelerations and decelerations in the growth rate of money lead mainly to short-run fuctuations in output and employment. ${ }^{4}$

These short- and long-run effects of money stock growth on prices, output, and employment are demon-

In the equation formulated by Leonall $C$. Andersen and Jerry L. Jordan, a marked and sustained change in monetary growth has its major effect on nominal GNP within five guarters. See Leonall C. Andersen and Jerry L. Jordan, "Monetary and Fiscal Actions: A Test of their Relative Importance in Ecomomic Stabilization," this Review (November 1968), pp. 11-24.

Equations formulated by Leonall $\mathrm{C}$. Andersen and Keith $\mathrm{M}$. Carlson indicate that monetary actions generally affect total spending with a two-tothree quarter lag. A change in the rate of growth of total spending was accompanied by a simultaneous change in the rate of growth of ontput. Prices changed nore slowly following a change in total spending. See Leonall $C$. Andersen and Ke:th M. Carlson, "A Monetarist Model for Economic Stabilization," this Review (April 1970), pp. $7-25$.

4In "Money Supply and Time Deposits, 1914-69," this Review (March 1970), pp. 6410, changes in money growth rates and cyelical movements in economic activity were compared. 
strated on Chart $I^{5}$ The trend rate of growth of the money stock, as shown in the top tier, increased from a 1.7 percent annual rate through most of the $1950 \mathrm{~s}$ and early $1960 \mathrm{~s}$, to 3.7 percent in the first half of the $1960 \mathrm{~s}$, and to 5.8 percent in the second half of the $1960 \mathrm{~s}$ and early 1970s. The trend rate of growth of prices, as shown by the General Price Index panel, rose in a similar pattern from the 1950 s through the 1960 s, reflecting, after about a three year lag, changes in the trend growth of the money stock.

Relationships between output and employment and the growth of the money stock relative to its underlying trend rates can be observed in the top and bottom tiers of Chart I. During the two decades covered, six periods of money stock growth occurred at rates significantly greater than the underlying trend. ${ }^{6}$ Each of these periods was accompanied (with a lag of one or two quarters) by an upward movement in real output toward or above potential real output as estimated by the President's Council of Economic Advisers.

During this same twenty year interval the economy experienced four recessions (as defined by the Naional Bureau of Economic Research) and two periods of brief economic slowdown. Each of the four reces. sions (shaded areas in Charts I and II) was preceded by a marked slowdown or an absolute decline in the rate of growth of the money stock. The recessions occurred in the periods 1953-54, 1957-58, 1960-61, and 1969-70. When the rate of growth of the money stock slowed in 1962 and 1966, the growth rate of real output slowed, and a rise in the rate of unemployment followed. The 1962-63 and 1966-67 periods of slow down were not of significant magnitude and duration to be labeled recessions.

Chart I does not offer conclusive evidence that monetary growth affects economic activity. However, the relationships shown on the chart are consistent with the view that the trend growth of money is a major influence on long-run price movements, and that accelerations and decelerations of monetary growth about the trend have predictable effects on output and employment in the short run." Price movements, on

5For econometric evidence supporting the interpretation of these charts, see Andersen and Carlson, "A Monetarist Model,"

6As used in this context, a period is a time interval of at least six months duration. These periods of accelerating money growth began in late $1951,1954,1958,1961,1965$, and 1968 .

FFor an elaboration of a theoretical foundation underlying these relationships, see Karl Brumner, "A Survey of Selected Issues in Monetary Theory," Schweizerische Zeitschrift fiir Volkswirtschaft und Statistik (No. 1, 1971), pp. 1-146. the other hand, have been little affected by short-run variations in monetary growth.

The experience of the last two decades also suggests that monetary growth has little lasting influence on the rate of unemployment and the growth rate of real output. ${ }^{8}$ Despite variations in the rate of monetary growth about its trend as well as changes in the trend in the $1950 \mathrm{~s}$ and $1960 \mathrm{~s}$, growth of real output tended to move towards or along its potential growth path. ${ }^{9}$ The unemployment rate averaged 4.9 percent from 1952 to 1962 and averaged 4.6 percent since then. The lasting effect of monetary actions is on the trend of prices, whereas output and employment growth depend on real factors - labor force trends and productivity.

\section{Determinants of the Money Stock}

In view of these observed relationships between money and economic activity, it is important to consider the factors which affect movements in the money stock. The money stock (M), defined in this article as demand deposits and currency held by the nonbank public, can be expressed as a function of the monetary base (B) and a money multiplier $(\mathrm{m})$ such that:

$$
\mathrm{M}=\mathrm{mB}
$$

Using this relationship, factors which cause the money stock to change can be summarized by changes in the monetary base and the multiplier.

The multiplier over the past twenty years has been fairly stable. ${ }^{10}$ It has fluctuated over a narrow range and has been shown to be predictable.11 Consequently, the trend rate of growth of the money stock has been dominated by the trend rate of growth of the monetary base. The close association between

sFor an explanation of this observation see Milton Friedman, "The Role of Monetary Policy," The American Economic Review (March 1968), pp. 1-17, and in The Optimum Quantity of Money and Other Essays (Chicago: Aldine Publishing Company, 1969), pp. 95-110.

"After the 1960-61 recession, the movement back toward potertial real output was relatively slow. This period followed two recessions only two years apart which provided a basis for the growing belief in the early 1960 s that the economy was becoming subject to relatively short business cycles. Such a belief was probably a contributing factor to the slow recovery to full employment in the early $1960 \mathrm{~s}$. In addition, the economy received a minor additional shock shortly after the $1960-61$ recession when money declined relative to the trend in 1962 .

10The money multiplier sumnarizes the decisions of commercial banks to hold excess reserves, of the Government to hold demand deposits, and of the public to hold currency, demand deposits, and time deposits. A discussion of factors affecting the money multiplier is presented by Jerry L. Jordan, "Elements of Money Stock Determination," this Review (October 1969), pp. 10-19.

11See Albert E. Burger, Lionel Kalish III, and Christopher "F. Babb, "Money Stock Control and Its Implications for Monetary Policy, this Review (October 1971), pp. 6-22. 
Intluence of Noney on Prices, Output and Unemployment

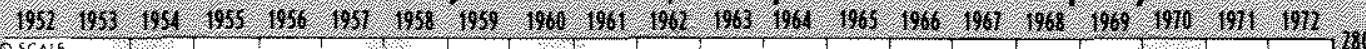

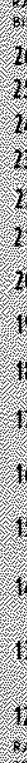

26. Money Stock

10. Searematly A Éjusted

30

Im:

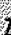

19

18

ro

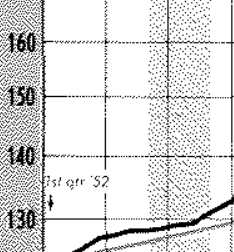

170

10 General Price Index

10

14

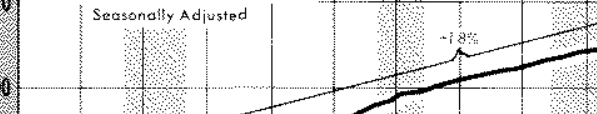

of

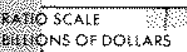

60. Real Output

Pintential gip

Sil $-\quad$

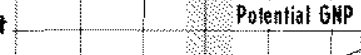

$+$

Real GHP

40

thin
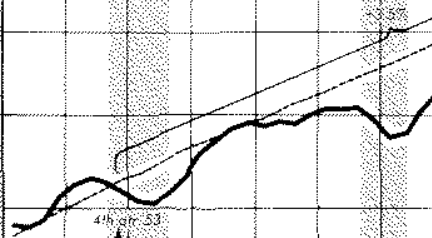

Unemployment Rate

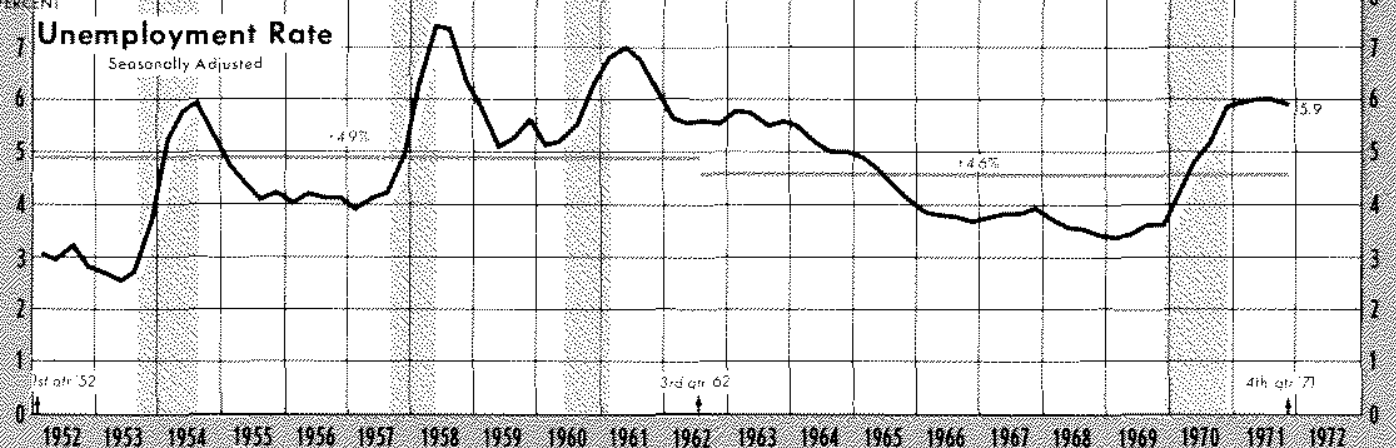


Influence of Federal Government Debt on Monetary Expansion

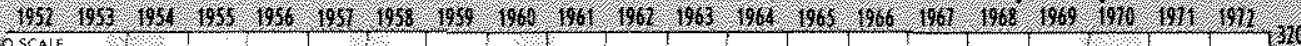

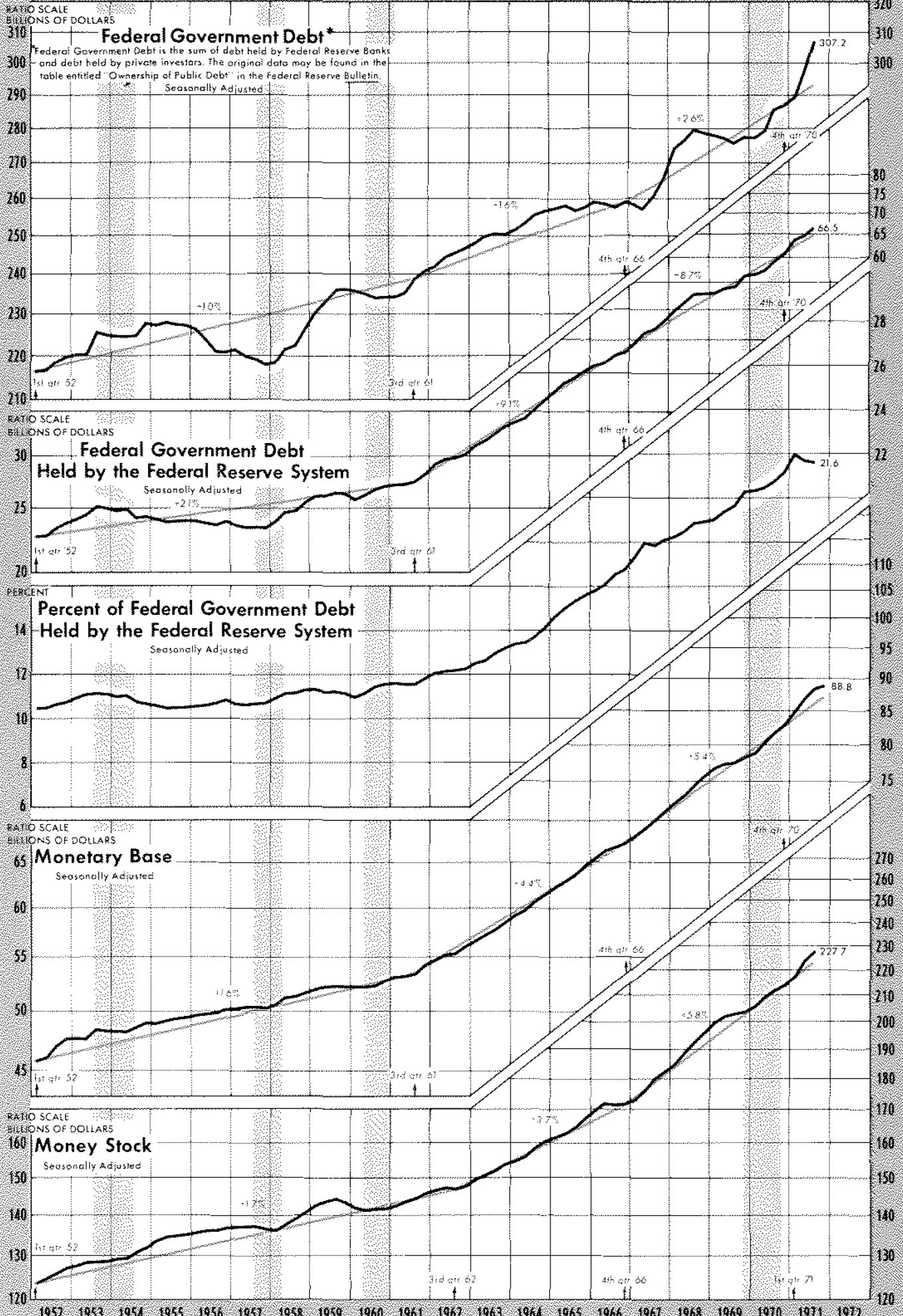




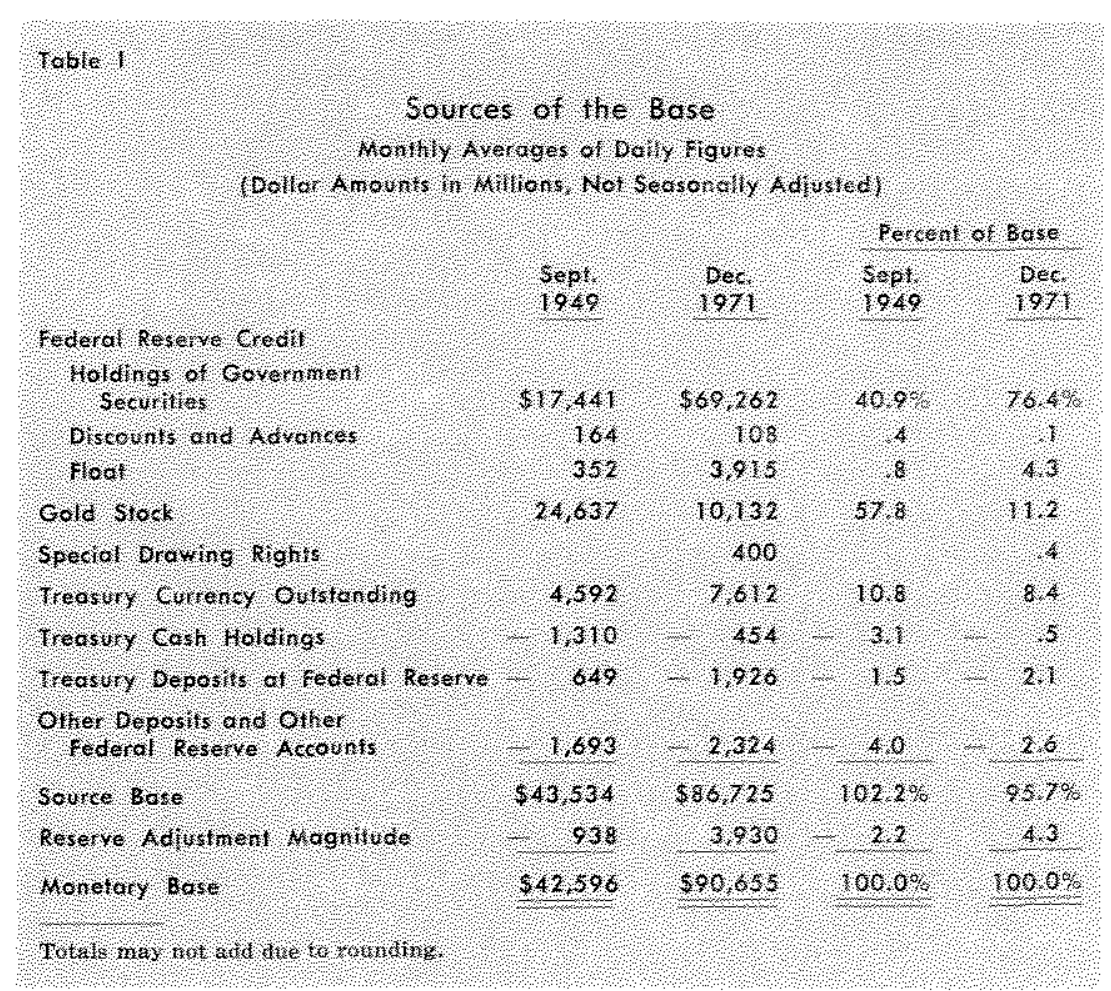

the monetary base (Table I). Since 1949, the amount of gold held has declined almost continuously. The de cline in gold stock has contributed a negative influence to growth of the base, while increases in Federal Reserve holdings of U.S. Government securities, the dominant component of Federal Reserve credit, has contributed a positive infuence. Other sources, though their net influence has been positive, have contributed relatively little to movements in the base during the past twenty years.

From 1952 to the middle of 1961 , increases in securities held by the Federal Reserve Systen almost offset decreases in the gold stock. The monetary base grew slowly in this period. Beginning in the $1960 \mathrm{~s}$, increases in Federal Reserve holdings of Govemment securities more than offset reductions in the gold stock, and the these two rates is indicated by the trend lines in the bottom two panels of Chart II.

The monetary base represents the net monetary liabilities of the Government (U.S. Treasury and Federal Reserve System) held by the public (commercial banks and nonbank public). The monetary base has been referred to as "high powered" money because it can be used as reserves of commercial banks to expand demand deposits by more than the amount of reserves. ${ }^{12}$

Given that changes in the monetary base are the major determinant of changes in the rate of monetary expansion, it is important to ascertain the ractors which have led to changes in the base. Table I presents the sources of the monetary base. Growth of the monetary base during the past twenty years has been determined primarily by two sources - Federal Reserve Credit and the gold stock. An increase in the dollar amount of ether of these sources, other things equal, increases the monetary base by an equal amount.

In September 1949, when the gold stock somree of the base was at its peak, it comprised 57.8 percent of

$12 \mathrm{~A}$ discussion of the monetary base is presented by Leonall C. Andersen and ferry L. Jordan, "The Monetary Base Explanation and Aralytical Use," this Review (August 1968), pp. $7-11$. monetary base grew more rapidly. A two-tiered gold system, established in March 1968, separated the gold market into private and official sectors, each with its own price. Since April 1968, the gold stock has remained roughly constant and has contributed little to growth of the monetary base. Gold now represents only 11.2 percent of the base.

Holdings of Government securities by the Federal Reserve represent the System's acquisitions of Federal Government debt through its open market operations. These security holdings presently comprise 76.4 percent of the monetary base, and since the early 1960 s changes in security holdings have been the dominant infuence on growth of the base. Through purchases and sales of securities, called open maket operations, the Federal Reserve can control the growth of the monetary base by oflsetting or complementing any movements in other sources.

\section{Infuence of the Federal Government Debt on Monetary Expansion}

Growth of Goverment securities held by the Federal Reserve System depends on the growth of Goyemment debt and the percent of this debt the System decides to purchase. This section traces the growth of Govemment debt over the last twenty years, the acquisition of debt by the Federal Reserve System and the reasons for debt acquistion by the System. 


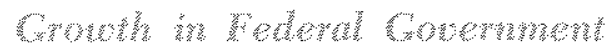

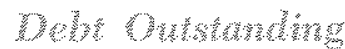

Growth of Government debt is shown in the top tier of Chat II." Goverment debt outstanding oscil. lated around a one percent anmual trend rate of growh from the first quarter of 1952 to the third quarter of 1961 . Unifed budget deficits of $\$ 3.4$ bnlion and $\$ 7.1$ in fiscal years 1961 and 1902 , respectively, initiated an increase in the trend rate in the early 1960s. From the third quarter of 1981 to the fourth quarter of 1966, Government debt rose by $\$ 20.2$ billion, ot at an mual trend rate of 1.6 percent.

Large unified budget defics of $\$ 8.7$ billion and $\$ 25.2$ billon were incurred in fiscal years 1967 and 1968, respectively. These deficits further increased the trend growth rate of Govermment debt. From the fourth quarter of 1966 to the tourth quarter of 1970 Govemment debt grew by $\$ 27.8$ billion, or at a 2.6 percent anmual rate.

Govemment debt grew in the early 1960 s mainly because of deficits incurred in fiscal years 1961 through 1965. During this pertod outays for domestic civilian programs increased at about an 8 percent anmul rate and tax receipts rose at a 5 percent rate. The slower growth in tax receipts relected tax clis in 1962, 1964, and 1965. In the second half of the 1960s, de fense expenditures rose sharply, while at the same time nondefense expenditures accelerated further. These rapid expenditure increases were not acconpanied by increased tax rates, except in iscal 1969 , and as a result, large defcits were incurred in fiscal years $1967,1968,1970$, and 1971.

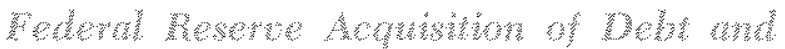

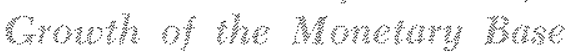

Federal Government debt held by the Federal Re serve System changed lithe in the 1950s, but then grew rapidy in the 1960 s. Changes in the monetary base dung the $1900 \mathrm{~s}$ roughy paralled that of the System's holding of debt. Dobt acquisition by the Federal Reserve System and the percent of debt held by the System are shown on Chart II (second and thind panels from the top).

Between the fist quarter of 1952 and the third quarter of 1981 , the proporion of Govemment debt held by the Federal Reserve System remaned roughly constant at around 11 percent. As Govemment debt incrensed, secunties held by the Federal Reserve System increased proportionaly, and as the debt de-

\footnotetext{
13 Federal Government debt is defined in this article at the sum of debt held by Federal Reserve Banks and debt held by private investors. The original data may be found in the tabe enthed "Ownerhop of pubine Debt" in the Federal Reserve Bullotin.
}

creased, securities held decreased proportionally. Variations in Govermment debt outstanding in the 1950s, especially late in the decade, tended to accelerate and clecelerate growth in the monetary base. Variations in the base, in turn, were a major cause of fuctuations in the money stock.

When the trend rate of growth of Government debt increased in the first half of the 1960 , the percent of the debt held by the Federal Reserve also increased, as the rate of acquision of debt by the Federal Reserve was mone rapid than the expansion of the Gov. ermment debt itself. Increased purchases of Government securities by the Federal Reserve directly increased the monetary base, increasing its trond rate of growth, which in turn increased growth of the money stock and economic activity. As resource utilization approached its upper limit, as defined by potential output, the rate of inflation increased.

From the third quarter of 1961 to the fouth quarter of 1966, the Federal Reserve purchased $\$ 15.9$ bilhion of Goverment securities adding to its portfolio at a 9.1 percent average annal rate. The effect of debt acquisition on growth of the monetary base was partially offset by at $\$ 4.3$ billion decline in the gold stock, and the monetary base grew by $\$ 13.7$ billion. This increase accelerated growth of the base to a 4.4 percent annual rate, and growth of the money stock began to accelerate in the third quarter of 1962. Real output grew with litte effect on prices until 1965 when a high level of resource utilization was reached and price increases began to accelerate.

The Federal Reserve continued to rapidly increase its security holdings in the second half of the 1960 s, when growth of the debt accelerated further. As a result, growth of the monetary base, money stock, and prices accelerated. From the fourth quarter of 1966 to the fourth quarter of 1970. Govemment debt held by the Federal Reserve grew by $\$ 17.2$ billion, or at an 8.7 percent annual rate. As a consequence, the portion of debt held by the Federal Deserve increased from 16.8 percent in late 1966 to 21.1 percent in late 1970. The base increased by $\$ 16$ billon, accelerating to a 5.4 percent ammal rate of growth. Money stock growth accelerated to a 5.8 percent annual rate during this period and the rate of increase in prices climbed to a 5.1 percent rate beginning in the second quarter of 1969 .

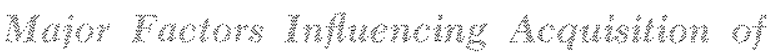

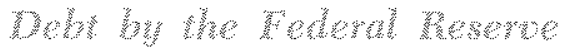

The FederaI Reserve System purchases Government securities for several purposes. However, conm 


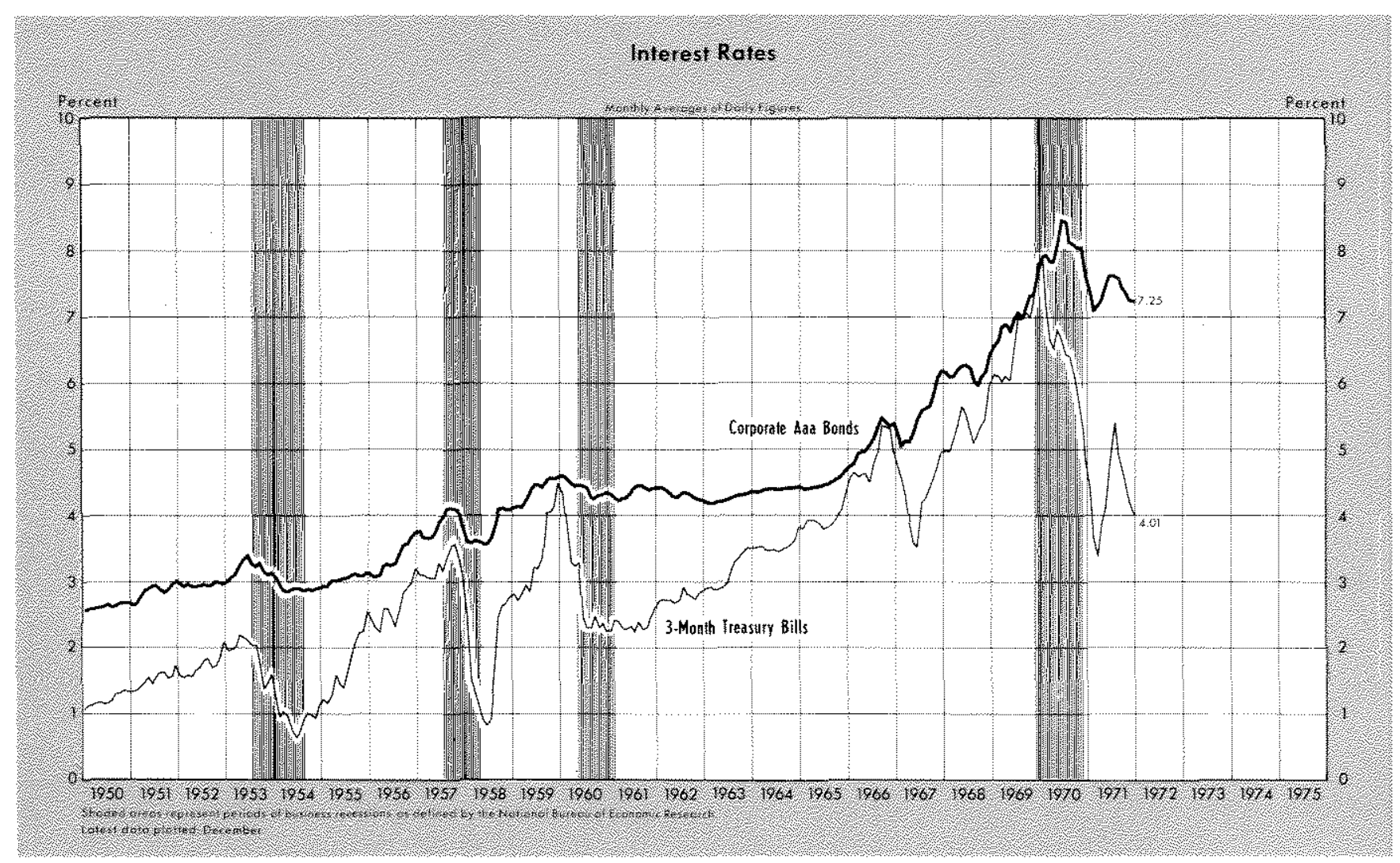

cem over market interest rate movements has been a major factor influencing Federal Reserve acquisition of Govemment debt over the last two decades. ${ }^{14}$ Debt issues by the Federal Govemment put tpward pressure on interest rates. When the Federat Reserve System buys Federal Government debt in the open market, both the supply of credit and the money stock are increased. Greater availability of funds in the credit markets initially puts downward pressure on interest rates. System actions are thereby capable of preventing interest rates from rising during times of Treasury borrowing.

Purchases of securities also increase the monetary base which produces an expansion in the money stock. If growth of the money stock is greater than increases in the demand for money balances, then the difference will tend to be reflected in an increase in aggregate demand. An increase in aggregate demand stimulates economic activity and tends to increase the demand for credit placing upward pressure on market

1+Michael W. Keran and Christopher T, Babb, using regression analysis, found that changes in Federal Reserve holdings of Govermment securities and changes in the monetary base were intuenced, in descending order of importance, by market interest rates, changes in the amount of United States Covernment debt outstanding, and economic stabilization objectives. See Michael $W$, Keran and Christopher

T. Babb, "An Explanation of Federal Reserve Actions (1933-68)," this Review (July 1969), pp. $7-20$. interest rates. If prolonged price increases acoompany an acceleration in total spending, expectations of future price increases develop. Borrowers are then willing to pay and lenders demand an inflation premium which raises market interest rates. Thus, sustained increases in the money stock usually exert upward pressure on interest rates.

The initial, shott-run impact of its security purchases on interest rates generally has received the greatest attention in the day-to-day operations of the Federal Reserve System. Large debt acquisition by the System has resulted from attempts to maintain existing money market conditions during times of Treasury borrowing. The positive longer-rum impact of monetary expansion on interest rates has been a factor leading to an accelerating trend rate of growth of the money stock in the $1960 \mathrm{~s}$.

Variability around trend movements of the monetary base may be attributed in considerable measure to alternating concern between reducing inflation and facilitating a relatively rapid economic expansion to lower the rate of unemployment. When the rate of inflation intensified monetary authonities sought higher interest rates; consequently, the rate of growth of the base (and money stock) slowed markedly for a period. Shortly thereafter econonic activity slowed and unem- 
ployment rose. Monetary authorities then shifted objectives and attempted to lower market interest rates to stimulate economic activity; consequently, the base increased more rapidly. This rapid monetary expansion, after a lag, placed further upward pressure on prices, setting the basis for a future round of monetary restraint. ${ }^{15}$

\section{Conclusions}

This article emphasizes a number of propositions which may be summarized as follows:

1. The trend rate of growth of the money stock plays a major role in determining the trend rate of growth of prices. Marked and sustained changes in the growth rate of the money stock are followed by short-run variations in output and employment.

${ }^{15}$ Examples of such short-run destabilizing monetary actions have been noted in this Bank's Review. See Reprints 17, 22, $28,39,57$, and 68 , for ammual reviews of monetary actions for the years 1965 through 1970 , respectively. A study of the released "Minutes of the Federal Open Market Conmittee" for the years prior to 1965 indicates that monetary developments were similar in earlier years.
2. Growth of the money stock is dominated by growth of the monetary base.

3. Even though monetary athorities can independently control movements in the monetary base, growth of the base has been greatly infuenced by growth of Government debt and concem about movements in market interest rates.

A steady, moderate rate of monetary expansion can help foster noninflationary growth and promote stability. Such a course of monetary expansion may be difficult to achieve at the present time, unless impediments to such expansion are reduced. The Federal Government deficit during fiscal year 1972 is expected to be extremely large, representing a substantial demand for credit, which in turn, would be expected to exert upward pressure on market interest rates. Public sentiment against high or rising interest rates is deeply imbedded in traditional American thought. A step towards lessening the infuence of these impediments would be for market interest rates to receive loss emphasis in the detemination of monetary actions. 